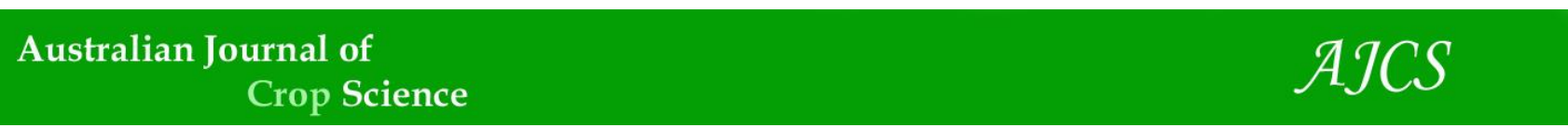

AJCS 15(04):505-509 (2021)

ISSN:1835-2707

doi: 10.21475/ajcs.21.15.04.p2749

\title{
Physical characterization of gabiroba fruits (Campomanesia adamantium) from Brazil neotropical savanna
}

\section{Elias Emanuel Silva Mota ${ }^{1}$, Italo Marcelino Mateus ${ }^{1}$, Luciana Borges e Silva², Kátia Freitas Silva*2, Elitânia Gomes Xavier ${ }^{1}$, Joseanny Cardoso da Silva Pereira ${ }^{1}$, Camila Cardoso ${ }^{1}$}

\author{
${ }^{1}$ Evangelical College of Goianésia - Faceg, CEP 76380-000, Goianésia, GO, Brazil \\ ${ }^{2}$ Goiano Federal Institute, Ceres Campus, CEP 76300-000, Ceres, GO, Brazil
}

\author{
*Corresponding author: kfreitas2013@outlook.com
}

\begin{abstract}
Gabiroba is a species with potential for commercial cultivation due to its desirable agronomic characteristics, such as high yield and high levels of soluble solids. The objective of this study was to characterize fruits and seeds phenotypically and to evaluate the genetic structure in three natural subpopulations of Campomanesia adamantium, based on quantitative data. Fruits of gabiroba plants from three subpopulations were collected, sampling 10 mother plants per subpopulation, with collection of at least 10 fruits per matrix, totaling 300 fruits. Physical characterization data of fruits and seeds were submitted to descriptive analysis, analysis of variance and correlation among characters. There was significant variation for the length, width and fruit mass in $C$. adamantium at all hierarchical levels evaluated: among subpopulations and among mother plants within subpopulations. Most of the variation, for the three variables under study is found among fruits within mother plant, and then, there is greater variation among mother plants within subpopulation. The levels of variation found within the subpopulations were low. The correlation analysis demonstrated the existence of positive and high correlations between the variables such as, fruit length and fruit width, fruit length and fruit mass, fruit width and fruit mass. For a possible breeding program and / or conservation of the species, it is recommended to represent large number of subpopulations to ensure an adequate representativeness of the observed variability.
\end{abstract}

Keywords: Fruit and seed morphology; Cerrado; Phenotypic variation; Genetic structure.

\section{Introduction}

Gabiroba (Campomanesia adamantium O. Berg) belongs to the Myrtaceae family, which has approximately 26 genera and 1000 species described in the Brazilian flora (Souza and Lorenzzi, 2008). Gabiroba trees occur in abundance in phytophysiognomies, cerrado, cerradão, dirty camp (Silva et al., 2001) and rural physiognomies (Durigan et al., 2004).

C. adamantium is a shrub that can reach up to $2.0 \mathrm{~m}$ in height. They have solitary and androgynous flowers, formed from September to October with fruit ripening in the months of November and December (Durigan et al., 2004; Lorenzzi et al., 2006), it is also found in grouped populations, has annual fruiting and blooms for a short period of time (Silva et al., 2001). Its fruits have a round shape, ranging in color from dark green to light green and yellow, with a sweet and quite pleasant aroma (Vallilo et al., 2006).

It is a species with potential for commercial cultivation due to its high yield and high levels of soluble solids (brix) (Melchior et al., 2006) and high nutritional composition (Vallilo et al., 2006). Its fruits have the potential to be used in natura in the food industry and as flavorings in the beverage industry due to its juiciness, mineral content, fiber and interesting bioactive substances from the nutritional and functional point of view, as phenolic compounds (Viscardi et al., 2016).
It is considered a medicinal plant for its anti-diarrheal, purifying, anti-rheumatic properties, indicated for reducing the level of cholesterol in the blood. Its peels and leaves are used in the form of teas (Biavati et al., 2004). Sá et al. (2017) still report that oils extracted from gabiroba flowers and leaves have antifungal activities.

This species, originally abundant in its habitat, today, is under strong pressure due to the impact caused by the fragmentation of its subpopulations, either by inadequate extraction or by the expansion of agricultural borders (Durigan et al., 2004). Thus, it is necessary to know about the genetic diversity of the species and aspects related to its propagation.

Studies of fruit biometrics and the germinative behavior of seeds are important for understanding the genetic variability between populations of the same species, and the relation between this variability and environmental factors can, therefore, be used in genetic improvement programs (Carvalho et al., 2003).

The objective of the current study was to characterize phenotypically the fruits and seeds and to evaluate the genetic structure in three natural subpopulations of Campomanesia adamantium, based on quantitative data, contributing to conservation measures and aid in future genetic improvement programs for the species. 


\section{Results and discussion}

\section{Analysis of variance and estimates of phenotypic parameters}

There was significant variation for the fruit length, width and mass of $C$. adamantium at all hierarchical levels evaluated: among subpopulations and among mother plants within subpopulations (Table 2). The data found are in agreement with studies carried out with other fruit species native to the Cerrado (Ganga et al., 2010; Moura et al., 2013; Mota et al., 2020; Novaes et al., 2018), in which, almost all, with few exceptions, of the evaluated fruit and seed characters showed significant variance in the hierarchical levels analyzed.

High levels of phenotypic variation were verified for the evaluated characters of $C$. adamatium. Most of the variation, for the three variables under the study, is found between fruits within mother plants, and then, there is greater variation among mother plants within subpopulation. The levels of variation found within the subpopulations were low (Table 2).

Other studies carried out with fruits and seeds of Cerrado species, Ganga et al. (2010) with mangaba (Hancornia speciosa Gomes), Mota et al. (2020) (2013) with baru (Dipteryx alata Vog.) and Novaes et al. (2018) with the cagaita (Eugenia dysenterica DC.) found greater variation among fruits within subpopulation for some characters and for others among mother plants within the studied subpopulations. Moura et al. (2013), in a study with pequi fruits (Caryocar brasiliense Camb.) found that most of the characters related to the analyzed fruit show greater variation among subpopulations and among regions.

The high phenotypic variation observed in the fruit length, width and mass in three subpopulations of $C$. adamantium may be formed by a genetic component and / or be due to the strong influence of environmental factors, such as climate, soil, age of the plant, conditions of anthropization, competition and even by the very genetic difference between individuals, however, through phenotypic results, preliminary indications can be obtained from the genetic structure of the subpopulations (Vieira et al., 2006; Ganga et al., 2010). However, the existence of phenotypic variations does not guarantee that the variations found are of genetic origin (Botelho, 1993).

\section{Phenotypic characterization}

The descriptive analysis of the three characters studied showed that the highest phenotypic coefficient of variation (CV\%) occurred for Fruit Mass (FM) (Table 3). This result was also observed in the studies carried out by Dresch et al. (2013), with gabiroba, in the Cerrado region (stricto sensu), in the city of Ponta Porã (MS) and also by Oliveira et al. (2011), in the city of Uberlândia - MG.

The average value detected for fruit mass was $3.164 \mathrm{~g}$. Subpopulation 1 (Pirenópolis - GO) had the highest average among the three studied locations (Table 3 ). The average value, as well as the subpopulation averages, found for FM in the present study were higher than those mentioned by Vallilo et al. (2006), who obtained an average fruit mass of $C$. adamantium of $2.300 \mathrm{~g}$. However, the same mean for FM was lower than that found by Oliveira et al. (2011), who working with gabiroba fruits collected in cerrado sensu lato, in the Plant Reserve of Itororó Hunting and Fishing Club, and in the legal reserve of the Água Limpa Farm of the Federal University of Uberlândia, in an area of cerrado sensu stricto, both in the city of Uberlândia-MG, they found an average value of $4.150 \mathrm{~g}$.

The average fruit length (FL) and width (FW) of the three subpopulations studied (Table 3) were lower than the average values cited by Oliveira et al. (2011) and Dresch et al. (2013), which were $19.39 \mathrm{~mm}$ and $17.42 \mathrm{~mm}$ for (FL); $18.30 \mathrm{~mm}$ and 16.71 for (FW), respectively. Arantes and Monteiro (2002), also found a higher value than the one found by this study for the average fruit length $(18.00 \mathrm{~mm})$. The fruit shape presented, in general, length (L) greater than width (W), with L / W ratio of 1.010 in the average of the subpopulations; measures that revealed rounded fruit (Table 3 ). The LD / TD ratio, longitudinal diameter (LD) and transverse diameter (TD) is an indicative of the fruit shape, and it is more rounded as the quotient approaches 1 . This characteristic is desirable by industries as it facilitates the operations of cleaning and processing (Pinto et al., 2003).

As for studies related to fruit seeds, six characters were analyzed in a subpopulation located in the municipality of Pirenópolis, Goiás. The analysis of variance showed that there is variation among $C$. adamantium genotypes (plants) (Table 4). The descriptive analysis of the six seeds studied characters showed that the highest phenotypic coefficient of variation (CV\%) occurred for number of whole seeds (NWS) and total seed mass (TSM) (Table 4), the same result was observed by Dresch et al. (2013) in a study carried out in the Cerrado region (stricto sensu), in the city of Ponta Porã (MS), with fruits of $C$. adamantium.

The general average found for $C$. adamantium plants in total seed mass and whole seed mass (whole and with embryo WSM), was $0.193 \mathrm{~g}$ and $0.061 \mathrm{~g}$, respectively (Table 4). The mass of the whole seed in this study was higher than the average values reported by Dresch et al. (2013), for seeds from small fruits $(0.025 \mathrm{~g})$ and seeds from large fruits $(0.050$ g).

The range of, minimum and maximum variation, for the number of whole seeds (NWS) was 1,000 and 6,000, respectively, and for the total number of seeds (TNS), it ranged from 4,000 to 8,000 (Table 4). Similar results were found by Dresch et al. (2013), who obtained amplitudes of variation for the number of whole seeds from 1 and 7 and for the total number of seeds, values ranging from 3 to 8 . Dresch et al. (2013) evaluated gabiroba seeds grouping them according to the dimensions of the fruits (S - small, MS medium small, $\mathrm{ML}$ - medium large and L-large), the averages reported by the authors ranged from 4.70 to 6.75 seeds per fruit, values contained within this study (Table 4).

The current study presented average values for seed length (SL) and seed width (SW) of $5.453 \mathrm{~mm}$ and $4.859 \mathrm{~mm}$ (Table $4)$, respectively. The averages for seed length and seed width are within the range reported by Dresch et al. (2013), who observed averages values for seed length ranging from 4.76 $\mathrm{mm}$ to $6.64 \mathrm{~mm}$, and variation in seed width from $2.03 \mathrm{~mm}$ to $2.24 \mathrm{~mm}$ for different fruit sizes.

Despite the high variation presented by the characters of $C$. adamantium evaluated in this study, there were no genotypes with significant and higher averages values (Table 4). However, genotype 7 (seven) showed higher averages for the characters TSM and TNS. Genotype 2 (two) also showed a higher mean for TSM and NWS. For selection of superior mother plants, it is suggested to collect a larger number of mother plants in the locations (subpopulations) with better performances.

In the analysis of the correlation between the fruit and seed characters sampled, a significant positive and high correlation can be observed between the variables: fruit 
Table 1. Sources of variation (SV) and expected mean squares (MS) according to the hierarchical statistical model.

\begin{tabular}{llll}
\hline SV & $\mathrm{DF}$ & $\mathrm{MS}$ & $\mathrm{E}(\mathrm{MS})$ \\
\hline Subpopulations & $\mathrm{S}-1$ & $\mathrm{Q}_{1}$ & $\sigma^{2}+9 \sigma_{M}^{2}+30 \sigma_{S}^{2}$ \\
Mother plants/Subpopulation & $\mathrm{M}-\mathrm{S}$ & $\mathrm{Q}_{2}$ & $\sigma^{2}+9 \sigma_{M}^{2}$ \\
Residue & $\mathrm{N}-\mathrm{M}$ & $\mathrm{Q}_{3}$ & $\sigma^{2}$ \\
Total & $\mathrm{N}-1$ & & \\
\hline
\end{tabular}

S: number of subpopulations $(S=3)$; $M$ : Total number of matices $(M=27)$ and $N$ : total number of fruits $(N=270)$. DF: degrees of freedom. Values of $k$, adapted from Anderson and Bancroft (1952).
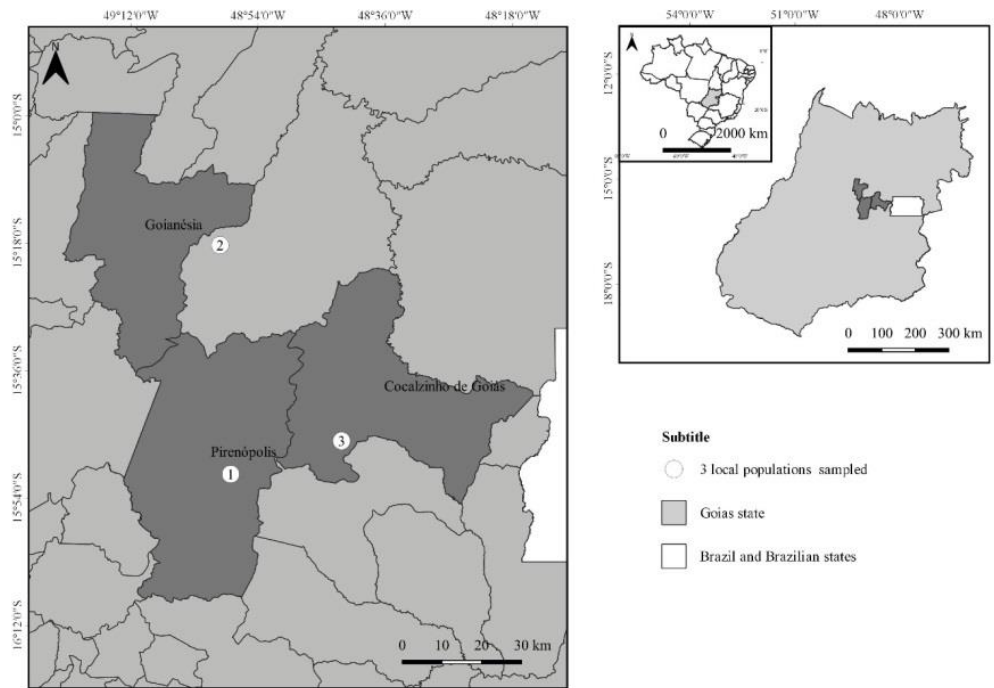

Fig 1. Map of the collection areas of three subpopulations of Campomanesia adamantium sampled in the city de Pirenópolis ( $\mathrm{n}$. 1), Goianesia ( $\mathrm{n}$. 2) and Cocalzinho de Goiás (n. 3) in the Brazilian Cerrado biome.

Table 2. Analysis of variance and estimates of phenotypic parameters for fruit length (FL), width (FW) and mass (FM), in three subpopulations of $C$. adamantium in the in the Brazilian Cerrado biome, 2018.

\begin{tabular}{lllll}
\hline \multirow{2}{*}{ Variation Sources } & \multirow{2}{*}{ DF } & \multicolumn{2}{l}{ Mean Square } \\
\cline { 3 - 5 } & & $\mathrm{FL}$ & $\mathrm{FW}$ & \multicolumn{2}{c}{$\mathrm{FM}$} \\
\hline Subpopulations & 2 & $23.295^{* * *}$ & $10.931^{*}$ & $5.3110^{* *}$ \\
Mother plants/Subpopulation & 21 & $15.727^{* * *}$ & $15.016^{* * *}$ & $4.7030^{* * *}$ \\
Residual & 216 & 2.6543 & 2.5016 & 0.7998 \\
$P_{s} \%$ & & 2.0800 & 0.000 & 0.5644 \\
$P_{m / s} \%$ & & 32.310 & 32.50 & 32.611 \\
$P_{f / m} \%$ & & 65.600 & 67.50 & 66.823 \\
\hline
\end{tabular}

${ }^{*}$ significant at $5 \%$ probability. ${ }^{* *}$ significant at $1 \%$ probability and ${ }^{* * *}$ significant above $1 \%$ probability. DF: degrees of freedom. $P_{s} \%$ : proportion of the total variance explained by differences among populations; $P_{m / s} \%$ : proportion of the total variance explained by differences among mother plants within the same population; $P_{f / m} \%$ : proportion of total variance explained by differences among fruits or seeds within mother plants.

Table 3. Average per subpopulation, minimum and maximum values (plant level) and coefficient of variation (CV\%) of the fruit morphological variables, of three subpopulations of $C$. adamantium from the Brazilian Cerrado biome, 2018. Fruit length (FL), Fruit width (FW) and Fruit mass (FM).

\begin{tabular}{llll}
\hline Subpopulation & FL & FW & FW \\
\hline 1- Pirenópolis & 17.00 & 16.78 & 3.373 \\
2- Goianésia & 16.83 & 16.53 & 3.107 \\
3- Cocalzinho & 15.76 & 15.91 & 2.779 \\
\hline Minimum & 12.47 & 11.98 & 1.290 \\
Maximum & 23.02 & 22.08 & 7.440 \\
Averages & 16.72 & 16.53 & 3.164 \\
\hline CV (\%) & 11.92 & 11.59 & 34.34 \\
\hline
\end{tabular}

Table 4. Average and average data (per seed), minimum, maximum values and coefficient of variation (CV\%) of the seeds morphological variables of a subpopulation of $C$. adamantium in the city of Pirenópolis - GO, Brazil, 2018. Total seed mass (TSM), whole seed mass (WSM), Number of whole seeds (NWS), Total number of seeds (TNS), Seed length (SL) and Seed width (SW).

\begin{tabular}{|c|c|c|c|c|c|c|}
\hline Genotype & TSM & WSM & NWS & TNS & $S L$ & SW \\
\hline 1 & $0.124 \mathrm{~b}$ & $0.063 a b$ & $1.500 \mathrm{c}$ & $5.600 \mathrm{ab}$ & $6.227 \mathrm{a}$ & $5.162 \mathrm{a}$ \\
\hline 2 & $0.238 \mathrm{a}$ & $0.051 \mathrm{ab}$ & $4.500 \mathrm{a}$ & $6.100 \mathrm{ab}$ & $5.453 \mathrm{~b}$ & $4.499 \mathrm{a}$ \\
\hline 3 & $0.219 \mathrm{ab}$ & $0.072 \mathrm{a}$ & $3.000 \mathrm{ac}$ & $5.300 \mathrm{~b}$ & $5.709 a b$ & $4.845 \mathrm{a}$ \\
\hline 4 & $0.211 a b$ & $0.071 \mathrm{ab}$ & $2.800 \mathrm{bc}$ & $6.100 a b$ & $5.416 \mathrm{~b}$ & $4.921 \mathrm{a}$ \\
\hline 5 & $0.181 \mathrm{ab}$ & $0.058 \mathrm{ab}$ & $3.100 \mathrm{ac}$ & $6.200 \mathrm{ab}$ & $5.249 \mathrm{bc}$ & $4.975 a$ \\
\hline 6 & $0.134 \mathrm{~b}$ & $0.050 \mathrm{~b}$ & $2.900 \mathrm{ac}$ & $5.500 \mathrm{ab}$ & 4.672 c & $4.820 \mathrm{a}$ \\
\hline 7 & $0.246 \mathrm{a}$ & $0.061 a b$ & $3.200 a b$ & $6.700 \mathrm{a}$ & $5.444 \mathrm{~b}$ & $4.789 a$ \\
\hline Minimum & 0.0770 & 0.030 & 1.000 & 4.000 & 3.110 & 3.720 \\
\hline Maximum & 0.4350 & 0.118 & 6.000 & 8.000 & 7.270 & 5.970 \\
\hline Averages & 0.1933 & 0.061 & 3.000 & 5.929 & 5.453 & 4.859 \\
\hline CV (\%) & 42.282 & 27.894 & 48.154 & 17.307 & 12.189 & 10.515 \\
\hline
\end{tabular}

In the column. averages followed by the same letters do not differ according to the Tukey test (5\%). 
Table 5. Analysis of Pearson's correlation coefficient among phenotypic variables of fruits and seeds of $C$. adamantium subpopulations of the Brazilian Cerrado biome, 2018.

\begin{tabular}{|c|c|c|c|c|c|c|c|c|c|}
\hline & $\mathrm{FL}$ & FW & FM & TSM & WSM & NWS & TNS & SL & SW \\
\hline $\mathrm{FL}$ & - & $0.906 * *$ & $0.921^{* *}$ & $0.409 * *$ & $0.100^{\mathrm{NS}}$ & $0.317^{* *}$ & $0.037^{\mathrm{NS}}$ & $0.154^{\mathrm{NS}}$ & $0.012^{\mathrm{NS}}$ \\
\hline FW & - & - & $0.951^{* *}$ & $0.428 * *$ & $0.087^{\mathrm{NS}}$ & $0.337^{* *}$ & $0.054^{\mathrm{NS}}$ & $0.239 *$ & $0.022^{\mathrm{NS}}$ \\
\hline FM & - & - & - & $0.487 * *$ & $0.152^{\mathrm{NS}}$ & $0.368 * *$ & $0.060^{\mathrm{NS}}$ & $0.234 *$ & $-0.010^{N S}$ \\
\hline TSM & - & - & - & - & $0.316^{* *}$ & $-0.212^{N S}$ & $0.748 * *$ & $0.247^{*}$ & $-0.174^{\mathrm{NS}}$ \\
\hline WSM & - & - & - & - & - & $-0.037^{N S}$ & $0.037^{N S}$ & $0.372^{* *}$ & $0.250^{*}$ \\
\hline NWS & - & - & - & - & - & - & $0.254^{*}$ & $-0.008^{N S}$ & $-0.266^{*}$ \\
\hline TNS & - & - & - & - & - & - & - & $-0.024^{N S}$ & $-0.090^{N S}$ \\
\hline SL & - & - & - & - & - & - & - & - & $0.009^{N S}$ \\
\hline sW & - & - & - & - & - & - & - & - & - \\
\hline
\end{tabular}

Fruit length (FL), Fruit width (FW), Fruit mass (FM), Total seed mass (TSM), Whole seed mass (whole and with embryo - WSM), Number of whole seeds (NWS), Total number of seeds (TNS), Seed length (SL) and Seed width (SW). NS $=$ not significant ${ }^{*}$ significant at $5 \%$ probability and ${ }^{* *}$ significant at $1 \%$ probability and ${ }^{* * *}$ significant above $1 \%$ probability.

length and fruit width (0.906), fruit length and fruit mass (0.921), width of the fruit and fruit mass (0.951). There was also a significant positive and average correlation for the total seed mass and number of whole seeds (0.748). Thus, fruits that are larger in length are also wider and heavier, and large fruits also have greater weight. It is also expected that the greater the total mass of the seed, the fruit will have a larger number of whole seeds.

According to Mota et al. (2020), when the phenotypic correlation coefficient is of high magnitude in absolute value, it means that both the genetic and environmental correlation must also be of high magnitude. When the phenotypic correlation is of low magnitude, what can happen is that its components are also of low magnitude or that present opposite signs.

\section{Materials and methods}

\section{Location of study}

The collection of the material for the current study was carried out in the Midwest region of the State of Goiás, Brazil, in December 2017. According to Köppen, the region has a tropical savanna climate with dry winter and rainy summer (Aw) (Alvares et al 2013). The analysis was performed in the Phytotechnics Laboratory, of the Evangelical College of Goianésia, Goiás, Brazil.

\section{Treatments and experimental design}

Three subpopulations of Gabiroba (Campomanesia adamantium) (Figure 1) and 10 mother plants per subpopulation were selected in the study area for collection of 10 fruits per matrix.

The experimental design adopted corresponds to the hierarchical model that considers the effect of subpopulations, mother plants within subpopulations and fruits within mother plants.

\section{Experimental procedures}

In each area, the matrix plants were found by walking in the respective places of occurrence, proceeding to the preselection of materials, sampling those with good phytosanitary aspect that had fruits for collection.

Fruit collection was carried out respecting their point of physiological maturation, which corresponds to the point at which they easily detach from branches or those that are already on the ground around the plants. The maturation period, in the collection region, corresponds to the month of December of 2017.

After harvesting, the fruits were packed and identified in plastic bags, placed in a thermal box with ice and transported to the laboratory. Due to the fact they are highly perishable fruits, they were kept in a refrigerator at $7 \stackrel{\circ}{ } \mathrm{C}$ for a short period of time, until the analysis was carried out, avoiding possible deterioration.

\section{Physical characterization}

A random sample of ten fruits per matrix was used for physical characterization, taking individual fruit mass data, using a digital scale with an accuracy of $1.0 \mathrm{mg}$; and fruit length $(\mathrm{mm})$ and width $(\mathrm{mm})$, using a digital caliper. Tenfruits per plant (mother plant), from a single subpopulation (Pirenópolis, GO), were opened to evaluate the variables: Total seed mass (TSM), Whole seed mass (whole and with embryo) (WSM), Number of whole seeds (NWS), Total number of seeds (TNS), Seed length (SL) and Seed width (SW). All measurements were taken in millimeters using a digital caliper. The individual identification of each matrix was maintained.

\section{Statistical analyses}

The data were submitted to descriptive statistics and, subsequently, the fruit data were subjected to analysis of variance based on a hierarchical model that considers the effect of subpopulations, mother plants within subpopulations and fruits within mother plants. The analysis was performed using the R software ( $R$ Core Development Team, 2013). The model used was:

$Y_{i j k}=\mu+S_{i}+P_{j(i)}+f_{k(i j)}$

where:

$Y_{i j k}$ : phenotypic value of fruit (or seed) $k$ from plant $j$ of subpopulation $i$;

$\mu$ : general mean of observed values;

$S_{i}$ : random effect of subpopulation $i, i=1,2, \ldots, S$, $\left[E\left(s_{i}\right)=0, E\left(s_{i}^{2}\right)=\sigma_{s}^{2}\right]$;

$p_{j(i)}$ : random effect of plant $j$ within subpopulation $i, j=1$, $2, \ldots, m_{i},\left[E\left(p_{j(i)}\right)=0, E\left(p_{j(i)}^{2}\right)=\sigma_{p / s}^{2}\right] ;$

$f_{k(i j)}$ : random effect of fruit $k$ within plant $j$ of subpopulation $i, k=1,2, \ldots, f_{j},\left[E\left(f_{k(i j)}\right)=0, E\left(f_{k(i j)}^{2}\right)=\sigma_{f / p}^{2}\right]$.

The sampling, when possible, was 10 mother plants per subpopulation $\left(m_{i}=10\right)$ and 10 fruits per matrix $\left(f_{j}=10\right)$, and in subpopulation three (local), they were found freiting only seven mother plants. According to the statistical model described above, the variance analysis scheme and the prediction for the mean squares were elaborated (Table 1).

The variance components associated with the effects of the model and the proportions of the total phenotypic variation were estimated, described by Mota et al. (2020), which is due to: difference among subpopulations $\left(P_{s}\right)$, difference among mother plants within subpopulations $\left(P_{m / s}\right)$ and 
difference among fruits within mother plants within subpopulations $\left(P_{f / m}\right)$.

The seeds deteriorated rapidly, thus, it was possible to evaluate only one subpopulation and seven mother plants. The data regarding to seeds were subjected to analysis of variance and when there was significance, the means were compared using the Tukey test (5\%).

Pearson's correlation coefficients among the evaluated characters were also estimated, based on a routine performed in the R software ( $R$ Core Development Team, 2013).

\section{Conclusions}

There is phenotypic variability among subpopulations and among mother plants within subpopulations for the species C. adamantium. Most of the genetic variability is found among fruits within mother plants and then, there is greater variation among mother plants within subpopulation. The highest coefficient of phenotypic variation, within the morphological variations, is due to the fruit mass. Larger gabiroba fruits also have greater fruit mass. For a possible breeding program and / or conservation of the species, it is recommended to represent large number of subpopulations to ensure an adequate representativeness of the observed variability.

\section{References}

Alvares CA, Stape JL, Sentelhas PC, de Moraes Gonçalves JL, Sparovek G (2013) Köppen's climate classification map for Brazil. Meteorologische Zeitschrift. 22 (3): 711-728.

Anderson RL, Bancroft TA (1952) Statistical theory in research. New York: McGraw-Hill Book Company, 399 p., 1952.

Arantes AA, Monteiro RA (2002) Família Myrtaceae na Estação Ecológica do Panga, Uberlândia, MG, Brasil. Lundiana. 3 (2): 111-127.

Biavatti MW, Farias C, Curtius F, Brasil LM, Hort S, Schuster L, Leite SN, Prado SRT (2004) Preliminary studies on Campomanesia xanthocarpa (Berg.) and Cuphea carthagenensis (Jacq.) J. F. Macbr. aqueous extract: weight control and biochemical parameters. Journal of Ethnopharmacology, Amsterdan. 93 (2): 385-389.

Botelho AS (1993) Características de frutos, sementes e mudas de Jatobá do Cerrado, Hymenaea stigonocarpa Mart. Ex Hayne de diferentes procedências. Tese (Doutorado em Ciências Florestais) - Ciências Agrárias, Universidade Federal do Paraná, Curitiba - PR, 93 p.,1993.

Carvalho JEU, Nazaré RFR, Nascimento WMO (2003) Características físicas e físico químicas de um tipo de bacuri (Platonia insignis Mart.) com rendimento industrial superior. Revista Brasileira de Fruticultura, Jaboticabal. 25 (2): 326-328.

Dresch DM, Scalon SPQ, Masetto TE, Vieira MC (2013) Germinação e vigor de sementes de gabiroba em função do tamanho do fruto e semente. Pesquisa Agropecuária Tropical, Goiânia, 43 (3): 262-271.

Durigan G, Baitello JB, Franco GAD, Siqueira MF (2004) Plantas do cerrado paulista: imagens de uma paisagem ameaçada. São Paulo: Páginas \& Letras, 1a ed., 475 p., 2004.
Ganga RMD, Ferreira GA, Chaves LJ, Naves RV, Nascimento JLD (2010) Caracterização de frutos e árvores de populações naturais de Hanconia speciosa Gomes do Cerrado. Revista Brasileira de Fruticultura, Jaboticabal. 32 (1): 101-113.

Lorenzi H, Bacher L, Lacerda M, Sartori S (2006) Frutas brasileiras e exóticas cultivadas (de consumo in natura). São Paulo: Instituto Plantarum, 1a ed., 640 p., 2006.

Melchior SJ, Custodio CC, Marques TA, Machado Neto NB (2006) Colheita e armazenamento de sementes de gabiroba (Campomanesia adamantium Camb. Myrtaceae) e implicações na germinação. Revista Brasileira de sementes. 28 (3): 141-150.

Mota EES, Novaes CRD, Silva LB, Chaves LJ (2020) Structure of the phenotypic variability of fruit and seeds of Dipteryx alata vogel (Fabaceae). Revista Brasileira de Fruticultura, Jaboticabal. 42 (05): e-003.

Moura NF, Chaves L, Naves RV (2013) Caracterização física de frutos de Pequizeiro (Caryocar brasiliense Camb.) do Cerrado. Revista Árvore, Viçosa. 37 (5): 905 - 912.

Novaes CRDB; Mota EES, Novaes E, Telles MPC, Chaves LJ (2018) Structure of the phenotypic variability of fruit and seed traits in natural populations of Eugenia dysenterica DC. (Myrtaceae). Revista Brasileira de Fruticultura, Jaboticabal. 40 (03): e-843.

Oliveira MC, Santana DG, Santos CM (2011) Biometria de frutos e sementes e emergência de plântulas de duas espécies frutíferas do gênero Campomanesia. Revista Brasileira de Fruticultura, Jaboticabal, 33 (2): 446-455.

Pinto WS, Dantas ACVL, Fonseca AAO, Ledo CAS, Jesus SC, Calafange PLP, Andrade EM (2003) Caracterização física, físico química e química de frutos de genótipos de cajazeiras. Pesquisa Agropecuária Brasileira, Brasília. 38 (9): 1059-1066.

R Core Development Team. R: A language and environment for statistical computing. Vienna: $R$ Foundation for Statistical Computing, 2013. Available in: <http:/www.Rproject.org/>. Access on: March,13 $13^{\text {th }}, 2017$.

Sá S, Chaul LT, Alves VF, Fiuza TS, Tresvenzol LMF, Vaz BG, Ferri PH, Borges LL, Paula JR (2017) Phytochemistry and antimicrobial activity of Campomanesia adamantium. Revista Brasileira de Farmacognosia. 28 (3): 303-311.

Silva DB, Silva JA, Junqueira NTV, Andrade LRM (2001) Frutas do Cerrado. Brasília: Embrapa Informação Tecnológica. 179 p., 2001.

Souza VC, Lorenzi H (2008) Myrtaceae. In: Souza VC, Lorenzi H Botânica sistemática: guia ilustrado para identificação das famílias de fanerógamas nativas e exóticas do Brasil, baseado em APG II, 2ª ed., Nova Odessa: Plantarum. 297303, 2008.

Vallilo MI, Lamardo LCA, Gaberlotti ML, Oliveira E, Moreno PRH (2006) Composição química dos frutos de Campomanesia adamantium (Cambesséde) O. Berg. Ciência e Tecnologia de Alimentos, Campinas. 26 (4): 725955.

Vieira RF, Costa TSA, Silva DB, Ferreira FR, Sano SM (2006) Frutas nativas da região Centro-Oeste. Brasília: Embrapa Recursos Genéticos e Biotecnologia, 1a ed., 320 p., 2006.

Viscardi DZ, Oliveira VS, Arrigo JS, Piccinelli AC, Cardoso CAL, Maldonade IR, Kassuya CAL, Sanjinez-Argandoña EJ (2016) Anti-inflammatory, and antinociceptive effects of Campomanesia adamantium microencapsulated pulp. Revista Brasileira de Farmacognosia. 27 (2): 220-227. 